Сазонець І. Л., д.е.н., професор, Саленко А. С., аспірант

(Національний університет водного господарства та

природокористування, м. Рівне)

\title{
СУТНІСТЬ ТА ТРАНСФОРМАЦІЯ ОСНОВНИХ ФОРМ ПІДПРИЕМНИЦЬКОї ДІЯЛЬНОСТІ
}

У статті розглянуто сутність підприємницької діяльності, розглянуто форми підприємницької діяльності. Серед таких форм підприємництва визначено: виробниче, комерційне, фінансове, високотехнологічне. Корпоративні форми організації підприємництва визначено основними. Виявлено чинники розвитку високотехнологічного корпоративного підприємництва. Надано перелік проблем розвитку підприємництва в Україні.

Ключові слова: підприємництво, сутність, форми, корпоративні, високотехнологічне, проблеми.

Постановка проблеми. Підприємницька діяльність $€$ головним економічним механізмом просування людської цивілізації до все більших економічних здобутків та революційних зрушень в науці, техніці, економіці, суспільному устрої, якості життя та світовому устрої. Розпочавшись з примітивних форм господарської діяльності, які ледь забезпечували спроможність існування людських спільнот, підприємницька діяльність трансформувалась у синтез різних форм ведення бізнесу разом із засобами виробництва і технологічними можливостями. Вона розвивалась у різних напрямках і з часом перетворилася на єдину різнопланову систему - основу світової економіки. 3 часом нові теорії, що пояснюють сучасний світовий економічний та суспільний устрій, такі як «постіндустріальна економіка», «економіка знань», «інформаційне суспільство», «інформаційна економіка», теорія циклів та технологічних укладів не розглядають сутність підприємницької діяльності як основи розвитку людства. Тому важливою науковою задачею $є$ подальший аналіз проблем трансформації онтології підприємницької діяльності та їі форм в сучасних економічних умовах.

Аналіз досліджень і публікацій. Серед науковців, що досліджували основи підприємницької діяльності слід визначити Валіулліну 3.В., Королевську Н.Ю., Курячу Н.В., Сазонець О.М., Сіпайло Л.Г., Сіпайло Н.О., Симків Л.Є. Сучасний розвиток економіки України, ї̈ ін- 
теграція в світове співтовариство, розвиток європейського вектору економічної та суспільно-політичної діяльності робить необхідним постійне вдосконалення форм і методів ведення міжнародного бізнесу, міжнародної торгівлі, механізмів залучення інвестицій в підприємницький сектор, що зумовлює необхідність вдосконалення наукового інструментарію дослідження трансформації основних форм підприємницької діяльності.

Невирішені раніше частини загальної проблеми. До наукових проблем, що раніше недостатньою мірою досліджувалися науковцями слід віднести зміну онтології трактування поняття «підприємництво» в сучасних реаліях розвитку інтеграційних процесів, розширення форм підприємницької діяльності, особливо в частині розвитку високотехнологічного підприємництва, появу нових факторів, що гальмують розвиток підприємницької діяльності.

Постановка завдання. 3 метою вирішення нових задач, що постають перед економічною наукою в питаннях дослідження сутності та трансформації основних форм підприємницької діяльності в статті поставлено задачу проаналізувати класичні та новітні підходи до сутності підприємництва, сучасні форми підприємницької діяльності з особливим акцентом на високотехнологічне підприємництва та проаналізувати основні причини, що заважають розвитку підприємницької діяльності в Україні.

Основні результати дослідження. Вітчизняними науковцями підготовлена велика кількість монографій, статей, підручників та навчальних посібників, що аналізують, досліджують, описують сутність підприємницької діяльності. Тією чи іншою мірою традиційні підходи до визначення сутності підприємницької діяльності знайшли своє відображення в Господарському Кодексі. Згідно Господарського кодексу України (ст. 42) підприємництво - це самостійна, ініціативна, систематична, на власний ризик господарська діяльність, що здійснюється суб'єктами господарювання (підприємцями) з метою досягнення економічних і соціальних результатів та одержання прибутку [4].

Безумовно в класичному розумінні підприємництво - це приватна ініціатива однієї чи більшої кількості осіб, що організували власний бізнес з метою отримання прибутку. В процесі вживання терміну «підприємництво» одразу уявляється приватне одноосібне чи невелике колективне підприємництво, яке працює в сфері послуг. Однак, така уява $є$ дещо застарілою. На теперішній час підприємництво охоплює всі сфери та галузі виробництва та регіони світу. Від допоміжного сектору виробництва воно стає глобальним потужним бізнесом, який змінює світ[8]. Одночасно, змінюються і підходи науковців щодо класифікації форм підприємницької діяльності. На теперішній час 
прийнято вирізняти наступні форми підприємницької діяльності:

виробниче підприємництво - це будь-яка матеріальна, інтелектуальна, творча діяльність, яка пов'язана з виробництвом продукції, товарів, наданням відповідних послуг, створенням певних духовних цінностей;

комерційне підприємництво характеризується діяльністю, яка пов'язана з операціями й угодами з купівлі-продажу товарів і послуг. В цьому бізнесі підприємець виступає в ролі торговця, комерсанта, який купує товари для подальшого перепродажу;

фінансове підприємництво - особливий вид комерційної діяльності, який пов'язаний з купівлею-продажем національної й іноземної валют і цінних паперів. Підприємець купує дані фінансові ресурси у їх власників, а потім з вигодою для себе перепродає покупцям;

високотехнологічне підприємництво - підприємницька діяльність в сфері високих технологій, в основу якої покладено інноваційні ідеї зі створення наукомістких товарів та/або послуг. Підприємцем у високотехнологічній сфері є талановита, освічена людина, яка, натрапивши на цінну наукову ідею, перетворює ії на сутність свого бізнесу [6].

Остання форма підприємницької діяльності є найбільш молодою за часом існування. Підприємницька діяльність в сфері високих технологій, наукові розробки, інвестиції в науку і освіту, підготовка висококваліфікованих кадрів та конкурентоспроможність національних економік значною мірою залежать від творчого потенціалу та креативних можливостей інноваторів [7]. Тож не дарма один 3 провідних фахівців-науковців у сфері інформаційної економіки Сазонець О.М., досліджуючи проблеми економіки знань, виокремила основні функції корпорації в сфері економіки знань:

формування стратегії та політики управління знаннями; придбання, засвоєння, передача знань (навчання персоналу); отримання або створення власними силами нових знань; оцінка (облік, моніторинг) знань і процесів їх виробництва;

включення нових знань до складу об'єктів інтелектуальної власності, нематеріальних активів;

захист знань, забезпечення інформаційної безпеки [1, С. 77].

Основною організаційною формою функціонування підприємницьких структур в сучасній економіці $\epsilon$ корпоративні форми. 3.В. Валіулліна в монографії «Концептуалізація діяльності корпорацій в інформаційно-інституційному середовищі» [2] наводить аналіз існуючих корпоративних форм організації бізнесу та підприємництва, характеризує методологічні основи розвитку інститутів корпоратив- 
ного управління, наводить періодизацію онтологічних підходів до діяльності корпорацій в інституційному середовищі та аналізує еволюційній характер розвитку корпоративного підприємництва в залежності в розвитку економічного середовища. За їі думкою на теперішній час корпоративні структуру, що $є$ ініціаторами та двигунами підприємництва формуються у відповідності до класифікаційних підходів, що подані на рисунку.

Розвиток підприємництва в Україні пов'язаний із низкою проблем:

- недосконалість та нестабільність законодавства у сфері розвитку підприємництва, що не дає можливості суб'єктам господарювання планувати свою діяльність на тривалий період;

- непомірний податковий тиск та нестабільність податкового законодавства, це призводить до того, що деякі суб'єкти малого та середнього підприємництва працюють в тіньовому секторі економіки;

- нестача внутрішніх фінансових ресурсів, складність доступу до зовнішніх джерел фінансування та залучення інвестицій, слабкі кредитні можливості підприємницьких структур;

- нерозвиненість інституцій ринкової інфраструктури підтримки підприємництва;

- ускладнений порядок проходження дозвільних (погоджувальних) процедур і, як наслідок, їх висока витратність;

- неналагодженість співпраці між органами самоврядування, місцевим бізнесом і недержавними організаціями;

- обмеженість інформаційного та консультативного забезпечення;

- відсутність дієвого механізму реалізації державної політики щодо підтримки та стимулювання розвитку малого бізнесу [5, С. 560564].

Висновки. Таким чином, спираючись на проаналізований теоретичний матеріал, необхідно зробити наступні висновки:

важливою науковою задачею $є$ подальший аналіз проблем трансформації онтології підприємницької діяльності та її форм в сучасних економічних умовах;

інтеграція України в світове співтовариство, розвиток європейського вектору економічної та суспільно-політичної діяльності робить необхідним постійне вдосконалення форм і методів ведення міжнародного бізнесу, міжнародної торгівлі, механізмів залучення інвестицій в підприємницький сектор, що зумовлює необхідність вдосконалення наукового інструментарію дослідження трансформації основних форм підприємницької діяльності; 


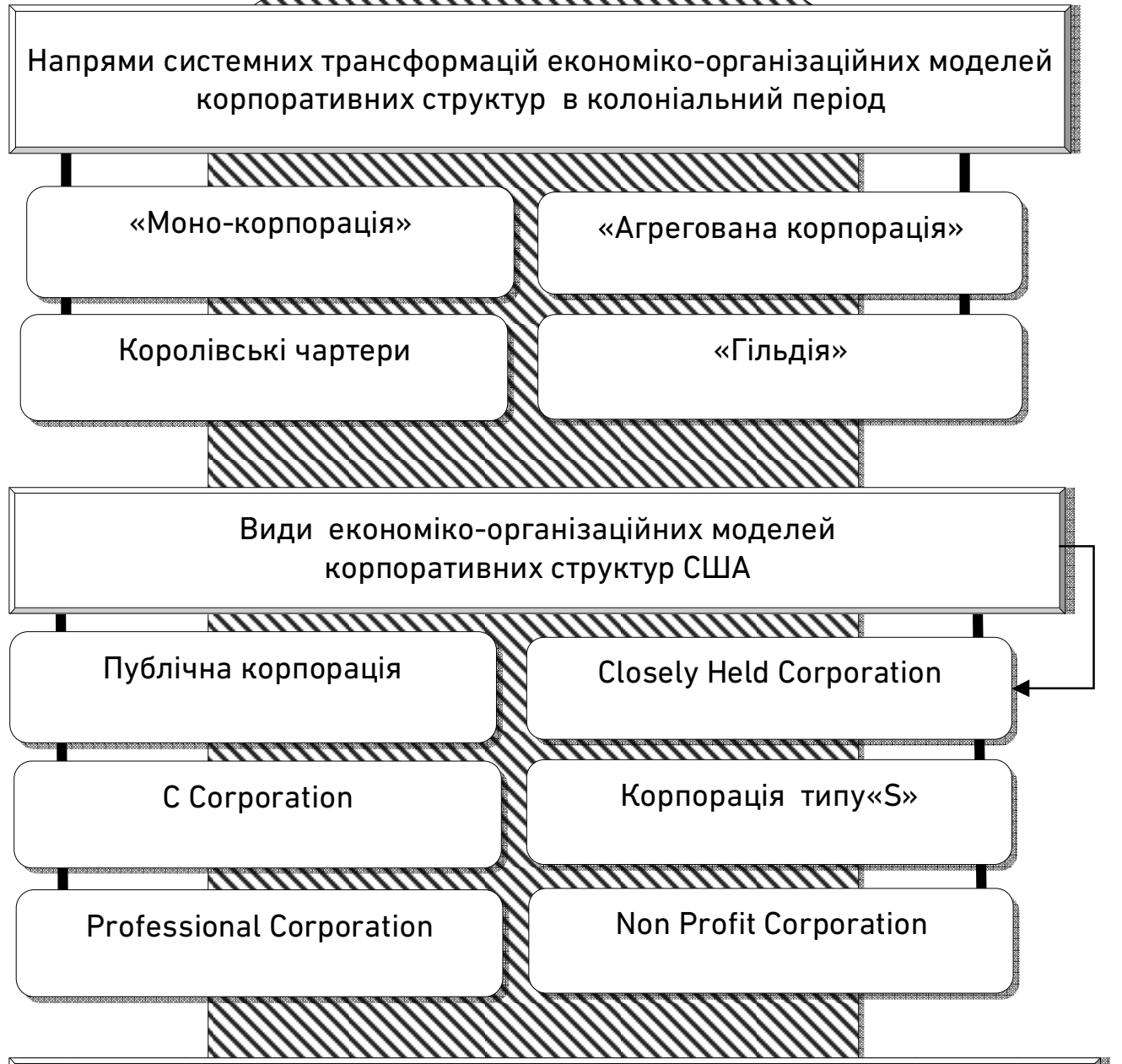

Напрями системних трансформацій економіко-організаційних моделей корпоративних структур в умовах інтернаціоналізації та інформатизації бізнесу

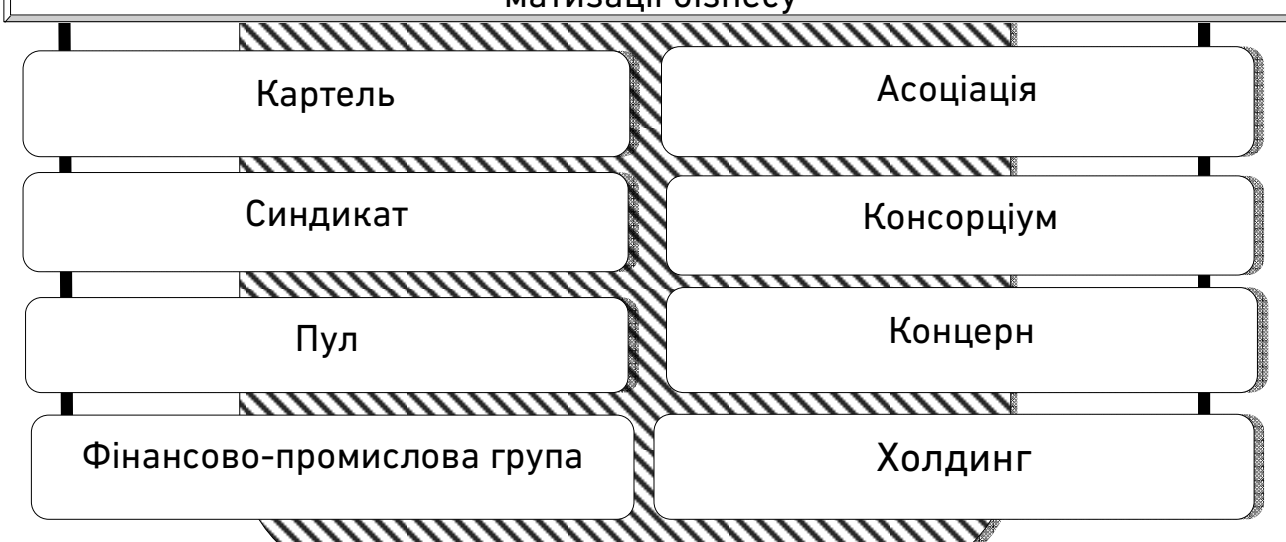

Рисунок. Трансформації економіко-організаційних моделей корпоративних структур [2] 
$€$ важливою задачею аналіз класичних та новітніх підходів до сутності підприємництва, сучасних форм підприємницької діяльності 3 особливим акцентом на високотехнологічне підприємництва та аналіз основних причини, що заважають розвитку підприємницької діяльності в Україні;

на теперішній час підприємництво охоплює всі сфери та галузі виробництва та регіони світу. Від допоміжного сектору виробництва воно стає глобальним потужним бізнесом, який змінює світ;

форма високотехнологічного підприємництва $є$ найбільш молодою за часом існування. Підприємницька діяльність в сфері високих технологій, наукові розробки, інвестиції в науку і освіту, підготовка висококваліфікованих кадрів та конкурентоспроможність національних економік значною мірою залежать від творчого потенціалу та креативних можливостей інноваторів;

основною організаційною формою функціонування підприємницьких структур в сучасній економіці є корпоративні форми.

1. Сазонець О. М., Пінчук О. Л., Куницький С. О. Глобальні інформаційні та наукометричні системи науково-технологічного розвитку України. Рівне : Волин. обереги, 2015. 184 с. 2. Королевська Н. Ю. Напрями розвитку та лібералізації підприємницької діяльності в Україні. Управління проектами та розвиток виробництва : зб. наук. праць. Луганськ : вид-во СНУ ім. В. Даля, 2011. № 3(39). С. 41-47. 3. Валіулліна 3. В. Концептуалізація діяльності корпорацій в інформаційно-інституційному середовищі. Рівне : Волин. обереги, 2018. 232 с. 4. Господарський кодекс України : Закон України від 16.01.2003 р. № 436-IV. URL: http://zakon.rada.gov.ua. (дата звернення: 15.01.2019). 5. Сімків Л. Є., Побігун С. А. Тенденції розвитку малого підприємництва в Україні в умовах диспропорційності економічного зростання. Глобальні та національні проблеми економіки : електронне наукове фахове видання. 2015. Вип. 3. С. 560-564. 6. Підприємництво. URL: https://uk.wikipedia.org/wiki/Підприємництво (дата звернення: 15.01.2019). 7. Сіпайло Л. Г., Сіпайло Н. А. Організаційно-економічні засади лібералізації інноваційного підприємництва : монографія. Рівне : НУВГП, 2018. 126 с. 8. Сазонець О. М., Куряча Н. В. Напрями лібералізації підприємницької діяльності в Україні в контексті вдосконалення системи пенсійного забезпечення. Проблеми економіки. 2015. № 4. С. 164-170.

\section{REFERENCES:}

1. Sazonets O. M., Pinchuk 0. L., Kunytskyi S. O. Hlobalni informatsiini ta naukometrychni systemy naukovo-tekhnolohichnoho rozvytku Ukrainy. Rivne : Volyn. oberehy, 2015. 184 s. 2. Korolevska N. Yu. Napriamy rozvytku ta liberalizatsii pidpryiemnytskoi diialnosti $\vee$ Ukraini. Upravlinnia proektamy ta rozvytok vyrobnytstva : zb. nauk. prats. Luhansk : vyd-vo SNU im. V. Dalia, 2011. 
№ 3(39). S. 41-47. 3. Valiullina Z. V. Kontseptualizatsiia diialnosti korporatsii v informatsiino-instytutsiinomu seredovyshchi. Rivne : Volyn. oberehy, 2018. 232 s. 4. Hospodarskyi kodeks Ukrainy : Zakon Ukrainy vid 16.01.2003 r. № 436-IV. URL: http://zakon.rada.gov.ua. (data zvernennia: 15.01.2019). 5. Simkiv L. Ye., Pobihun S. A. Tendentsii rozvytku maloho pidpryiemnytstva $v$ Ukraini $v$ umovakh dysproportsiinosti ekonomichnoho zrostannia. Hlobalni ta natsionalni problemy ekonomiky : elektronne naukove fakhove vydannia. 2015. Vyp. 3. S. 560-564. 6. Pidpryiemnytstvo. URL: https://uk.wikipedia.org/wiki/Pidpryiemnytstvo (data zvernennia: 15.01.2019). 7. Sipailo L. H., Sipailo N. A. Orhanizatsiino-ekonomichni zasady liberalizatsii innovatsiinoho pidpryiemnytstva : monohrafiia. Rivne : NUVHP, 2018. 126 s. 8. Sazonets O. M., Kuriacha N. V. Napriamy liberalizatsii pidpryiemnytskoi diialnosti $v$ Ukraini $v$ konteksti vdoskonalennia systemy pensiinoho zabezpechennia. Problemy ekonomiky. 2015. № 4. S. 164-170.

Рецензент: д.е.н.. професор Левицька С. О. (НУВГП)

Sazonets I. L., Doctor of Economics, Professor, Salenko A. S., Post-graduate Student (National University of Water and Environmental Engineering, Rivne)

\section{ESSENCE AND TRANSFORMATION OF BASIC FORMS OF ENTERPRISE ACTIVITY}

The article determines that an important scientific task is a further analysis of the problems of the transformation of the ontology of entrepreneurial activity and its forms in contemporary economic conditions.

It is proved that Ukraine's integration into the world community, the development of the European vector of economic and socio-political activity, makes it necessary to continuously improve the forms and methods of conducting international business, international trade, and mechanisms for attracting investments into the business sector, which necessitates the improvement of scientific instruments for studying the transformation of the main forms of entrepreneurial activity activities;

The analysis of classical and new approaches to the essence of entrepreneurship, modern forms of entrepreneurial activity with a special emphasis on high-tech entrepreneurship and analysis of the main reasons that hinder the development of entrepreneurial activity in Ukraine; 
It is shown that in the classical sense, entrepreneurship is a private initiative of one or more individuals who have organized their own business for profit. It has been determined that at present the business covers all spheres and industries and regions of the world. From the auxiliary production sector, it becomes a global, powerful business that changes the world;

It is proved that the form of high-tech entrepreneurship is the newest in existence. High-tech entrepreneurship is an entrepreneurial activity in the field of high technologies, which is based on innovative ideas for the creation of high-tech goods and / or services. Entrepreneur in the high-tech sector is a talented, educated person who, encountering a valuable scientific idea, turns it into the essence of his business and employment. Entrepreneurship in the field of high technologies, scientific developments, investments into science and education, training of highly skilled personnel and the competitiveness of national economies is significant To a degree, they depend on creative potential and creative possibilities of innovators;

It is determined that the main organizational form of functioning of business structures in the modern economy is corporate forms.

Keywords: entrepreneurship, essence, forms, corporate, high-tech, problems.

Сазонец И. Л., Д.э.н., профессор, Саленко А. С., аспирант (Национальный университет водного хозяйства и природопользования, г. Ровно)

\section{СУЩНОСТЬ И ТРАНСФОРМАЦИЯ ОСНОВНЫХ ФОРМ ПРЕДПРИНИМАТЕЛЬСКОЙ ДЕЯТЕЛЬНОСТИ}

В статье рассмотрена сущность предпринимательской деятельности, рассмотрены формы предпринимательской деятельности. Среди таких форм предпринимательства выделены: производственное, коммерческое, финансовое, высокотехнологичное. Корпоративные формы организации предпринимательства определены как основные. Выявлены факторы развития высокотехнологичного корпоративного предпринимательства. Дан перечень проблем развития предпринимательства в Украине.

Ключевые слова: предпринимательство, сущность, формы, корпоративные, высокотехнологичное, проблемы. 